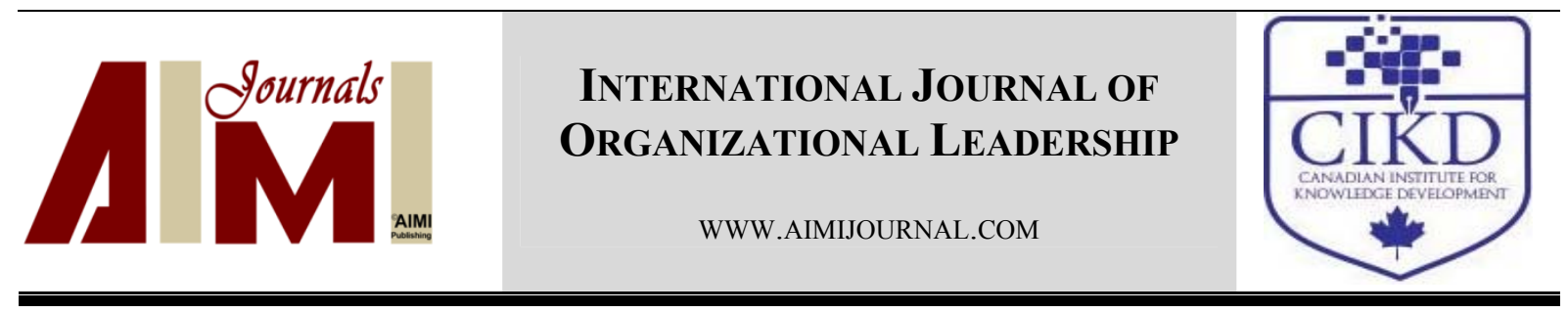

\title{
Leadership Styles of Hotel Managers in Northern Cyprus: Which Style is Dominant?
}

\author{
Özlem Uzunsaf Yamak ${ }^{1 *}$, Şerife Zihni Eyüpoğlu \\ ${ }^{1}$ The Near East University, School of Tourism and Hotel Management, Nicosia \\ ${ }^{2}$ The Near East University, Faculty of Economics and Administrative Sciences, Department of Business \\ Administration, Nicosia
}

\begin{abstract}
Keywords:

Leadership styles,

Demographic factors,

Hospitality Industry,

Northern Cyprus

\begin{tabular}{l}
\hline Received \\
08 June 2017 \\
Received in revised form \\
25 January 2018 \\
Accepted \\
31 January 2018 \\
\hline
\end{tabular}

The main aim of this study was to investigate the dominant leadership style of managers working in 4 and 5 star hotels in Northern Cyprus and to determine whether demographic factors influence their leadership styles. The leadership styles identified for the study were autocratic, democratic, laissez-faire, and charismatic. The demographic factors were gender, nationality, education level, management level, and job experience. A total of 120 managers participated in the study. The results indicated that charismatic leadership is the dominant leadership style and there is a statistically significant relationship between laissez-faire leadership style and the nationality of managers. However, no statistically significant relationship exists between leadership styles and the other demographic variables examined namely, gender, management level, education level, and work experience.
\end{abstract}

Correspondence:

ozlem.yamak@neu.edu.tr

(C)AIMI Journals

Leadership is a concept which is researched especially in the field of management and organisational science; however, it is much less known within the tourism industry. Leadership styles are important tools in creating motivated employees which in turn helps to achieve organizational goals (Kavanaugh \& Ninemeier, 2001). No doubt, in order to improve guest services, it is important to understand and employ the effective leaders in the hospitality industry.

Scholars have claimed that demographic dimensions influence people's values and attitudes which make them think and act in their own way (Chen \& Francesco, 2000; Mitchel, 2000; Tsui $\&$ O'Reilly, 1989), and those dimensions could also be used to understand the similarities or 
differences in the characters of effective leaders. For instance, according to Chen \& Francesco (2000), gender, age, and education have a noteworthy persuasiveness on leadership effectiveness. According to Fincham \& Rhodes, (2005), ineffective leadership results in employee stress, poor performance, and high staff turnover which mean suicide for organizations in the hospitality industry.

In this respect, the current study attempts to investigate the relationship between some demographic dimensions (gender, nationality, work experience, educational level, and management level) and leadership styles (autocratic, democratic, charismatic, and laissez-faire) among managers from 4 and 5 star hotels in Northern Cyprus. To this end, it is hoped that the study will contribute valuable information to the literature in regards to leadership styles of managers in the Northern Cyprus hospitality industry. Understanding this relationship is also important because it can help organizations in the hospitality industry to improve their leadership development process by enabling them to select people suitable for leadership positions and those who will bring success to hospitality organisations.

\section{State of Tourism}

Cyprus is an island situated in the Eastern Mediterranean. It gained independence from the United Kingdom in 1960. The island has been divided with a green line after 1974. Considering the Greek Cypriots living in the southern and the Turkish Cypriots living in the northern part of the island, Northern Cyprus has the typical features of an island economy. As a result of political isolation and embargoes faced by Northern Cyprus in every field, services sector was regarded more important than others with emphasis on higher education and tourism which respected as two major engines of economic development in the island since 1980.

Although isolation has been exerted on Northern Cyprus, the significance of tourism and hospitality industry can be perceived obviously regarding its perfect and undamaged natural beauty and cultural heritage (Nadiri \& Tanova, 2010). Therefore, the tourism industry, as it is in many islands in the Mediterranean and Aegean Sea countries, is the major contributor to the GDP as well as a creator of employment for a country. According to 2015 statistics, the net tourism income in Northern Cyprus was 746.7 million US dollars and tourism created 12,703 jobs (Northern Cyprus Statistical Yearbook of Tourism, 2015).

The main component of the tourism industry is the accommodation sub-sector. There are 134 accommodation establishments with a bed capacity of 21,543 in 2016. The most of the tourists are coming from Turkey and Britain. In 2016, total number of tourist arrivals were 1,330,146, but only 924,399 tourists accommodated in hospitality organisations with an average annual occupancy rate of $48.6 \%$ in 2016 (Northern Cyprus Tourism Statistics, 2016).

Casino tourism has shown special growth in Northern Cyprus after the mid-1990s. Since casinos were closed in Turkey, great investments on casinos have been made in Northern Cyprus by local investors as well as investors from Turkey. The visits from Turkey to the casinos in Northern Cyprus expands the occupancy rate at the weekends and official holidays. Also, cross border visits have begun between Northern and Southern Cyprus since April 23, 2003. Greek Cypriots have shown a great demand on casinos which reflects the economy of country (Gözel, 2011). In addition to wide range accommodation from 5 star hotels and holiday villages (mass 
tourism) Northern Cyprus also offers many special interest tourism including historical site visits, walks to endemics, turtle watching, and eco-agro village tourism.

Leadership has been defined in a variety of ways through the ages. According to Bass (1990), leadership is cooperation between two or more members of a group that often demands an arranging or rearranging of the condition and the insight and assumptions of the members. Northhouse (2007) defines leadership as a process whereby an individual influences a group of individuals to achieve a common goal. Kouzes and Posner (1995) describe leadership as the ability to mobilize people towards a shared vision, while encouraging individual development in the process. However, Yukl (2002) claims a more collective notion of leadership that requires a social influence process, whereby intentional influence is applied by an individual or a group over other people or groups to arrange the activities and relationships in a group or organisation.

\section{Leadership Styles}

As the definitions of leadership indicate, leadership is essential in influencing a group for achieving organisational goals. Thus, the style of a leader can be central for subordinates' approval of change motivation to attain elevated quality service (Bass \& Avolio, 1985). Leadership style can be defined as the pattern of behaviour that leaders act during work with and through others, as they perceive it (Robbinson, 2005). There are three factors that verify the type of leadership style, namely the leader's traits and characteristics, the subordinates' characteristics, and organizational environment (Kavanaugh \& Ninemeier, 2001). The most researched leadership styles are autocratic, democratic or participative, and laissez-faire.

The autocratic leadership style indicates that leaders have full organizational power and decision making authority. Democratic/participative leadership style indicates that leaders delegate and share their authority to make decisions with their subordinates. Laissez-faire leadership style implies that leaders give the authority to make decisions to their subordinates. Charismatic leadership style explains that leaders act as a role model for followers and display sense of power for decision making (Walter \& Bruch, 2009).

When we look at the management and the tourism and hospitality literature, it is observed that the use of certain leadership styles is widespread such as autocratic, democratic, laissezfaire, and charismatic (Kozak \& Uca, 2008) where styles are distinguished by the influence of leaders on subordinates (Mullins, 1998). The literature indicates that hospitality managers are authoritarian (Ispas, 2012; Okumuş \& Hemmington, 1998; Wood, 1994) because of unpredictable demands in the hospitality industry (Al-Ababneh, 2013) which requires off the cuff and ad ad hoc responses by management (Wood, 1994). Because demand is erratic, in order to manage labour effectively and achieve budgetary and revenue targets, managers have to react and in reacting, adjust inputs to outputs as best they can. Labour is the easiest input to adjust, and what might be regarded as sloppy personnel management in other industrial sectors is regarded as the norm in hotels and catering - sending staff home due to lack of business and hiring casual workers at short notice (Wood, 1994).

When probing the existing status of the hospitality industry one discerns that the hospitality leaders of today must be different. As Leavitt (2003) notes authority has never been enough to guarantee effective management and it is certainly not enough to handle middle manager's job today. In fact, democratic leadership style as the best alternative could be incorrect, because in 
some circumstances it is crucial to apply the autocratic leadership style, if this step could support the manager towards the accomplish of organisational goals (Raguz, 2007).

Leavitt (2003) states that due to the fast-changing, speeding world, managers must become equipped with many more skills and competencies than were required in the past. Managers now need to be imaginative, persuasive, visionary, and inspirational (Leavitt, 2003) to motivate followers to display appropriate behaviour (Newstrom, 2007).

\section{Leadership Styles and Demographics}

Upper Echelon Theory was proposed by Hambrick and Mason (1984). They theorized that demographic traits, namely age, tenure in an organization, functional area background, educational background, and degree of formal management training are all important aspects of leadership that influence the decisions they make and affect the organizational success. Previous researches related to the effect of demographic elements on leadership style have investigated the phenomenon from various perspectives.

Gender is one of the most researched aspects of leadership, however, findings are contradictory. According to Eagly and Johnson (1990), there were only little differences in leadership styles and gender. They claim that female leaders in organisational settings are inclined to be more democratic and participative compared to men, who tend to lean more towards autocratic behaviour. Raguz (2007) found that there is no interdependence between the hotel leadership style and the gender of managers. Another researcher found that males adopted a more transactional leadership style whereas women rather leaned towards a transformational leadership style (Rosener, 1990). Later this was established by a meta-analysis conducted by Eagly, Johannesen-Schmidt, and van Engen (2003).

From the available literature regarding nationality, it can be noted that it has influences on leadership styles. Nebel and Stears (1977) found that a task-oriented management style would be most effective in the North American hospitality industry. Testa (2007) found some significant differences (consideration or initiating structure, trust, and satisfaction) between culturally congruent (same nationality) and incongruent (different nationality). El Masry, Kattara, and El Demerdash (2004) investigated the differences and similarities between Egyptian and foreign hotel manager; according to them, there was no distinction in leadership efficacy. In addition, they stated that Egyptian general managers are more relationship-oriented while foreign general managers are more task-oriented.

In addition to gender and nationality, level of education is another demographic factor that may impact leadership behaviour. In literature, there is insufficient research to justify that leadership styles might be influenced by the level of education. According to the findings of Sawati, Anwar, and Majoka (2013) there was no significant association between the qualifications of the principles and their leadership style.

Work experience is another demographic factor. Jamrok and Neisari (2013) found that there existed a meaningful relationship between work experience and leadership style. However, according to Sawati, Anwar, and Majoka (2013) there was no significance among work experience and leadership behaviour.

When it comes to management level, Kozak and Uca (2008) found that there was a meaningful relationship between management level and leadership styles. 


\section{Research Questions}

The current study was twofold: Firstly, it investigated the relationship between hotel managers' leadership styles and demographic factors in Northern Cyprus; and secondly, it investigated the most common style of leadership amongst hotel managers in Northern Cyprus. More specifically, the following research questions guided the study:

- Which leadership styles are adopted by the managers of 4 and 5 star hotels?

- How significant is the relationship among leadership styles and managers' nationality?

- How significant is the relationship among leadership styles and managers' gender?

- How significant is the relationship among leadership styles and managers' management level?

- How significant is the relationship among leadership styles and managers' work experience?

- How significant is the relationship among leadership styles and managers' education level?

In our study, demographic factors, gender, nationality, work experience, education level, and management level are considered as the independent variables; and leadership styles namely autocratic, democratic, charismatic and laissez-faire are considered as the dependent variables. Figure 1 shows a conceptual model of the present study.

\begin{tabular}{|c|c|c|}
\hline Demographic Factors & Leadership Styles \\
Gender & Autocratic Leadership \\
Nationality & Democratic Leadership \\
Work Experience & Laissez-faire Leadership \\
Education Level & Charismatic Leadership \\
\cline { 2 - 3 } Management Level & \\
\hline
\end{tabular}

Figure 1. Hypothesized model of Relationships

\section{Method}

The study was conducted using the questionnaire method. An adapted version of the study instrument used in the Kozak and Uca (2008) study was applied. The study instrument consisted of two main parts: The first part aimed at revealing the demographic factors of the study respondents (hotel managers) and consisted of 5 questions. The second part of the questionnaire aimed at identifying the leadership styles of the study respondents. It included 28 items based on the four leadership styles, namely autocratic, democratic, laissez-faire, and charismatic. These 28 items measured using a five-point Likert type scales ranging from strongly disagree to strongly agree. Each leadership style was measured through seven items. The reliability coefficients (Cronbach's Alpha) for the autocratic, democratic, laissez-faire, and charismatic items were 0.83, 0.74, 0.78, and 0.73, respectively. Data analysis was conducted with SPSS 20.

According to the data of the North Cyprus Hoteliers Association-KTOB and the Ministry of Tourism, there were four 4-star and eighteen 5-star hotels at the time that the study was 
conducted. Three of the hotels were excluded from the sample because they did not agree to participate. Before conducting the field study, the human resource managers of the twenty-two 4-star and 5-star hotels were communicated by telephone for asking about the number of managers they employed. As a result, it was determined that there were 160 managers in total working at these hotels which made up the population for this study. Appointments were arranged for informing the participants about the purpose of the study to secure the confidentiality of the information provided. A total of the 120 questionnaire out of the 160 were returned, resulting in a $75 \%$ response rate.

\section{Results and Discussion}

Frequency analysis was used for looking at detailed research include formation on demographic data. To illustrate and explain the data collected, demographic profile of the respondents is displayed in Table 1.

As indicated in Table 1, out of the total number of respondents, $41(34.2 \%)$ were female and 79 (65.8 \%) were male. Concerning nationality, 57 (47.5\%) were Cypriot and 61 (50.8\%) were Turkish. Results indicate that $71(59.1 \%)$ of the respondents had a university degree and in terms of their level of work experience, 48 (40\%) had 6-10 years of job experience. Management level were split, only 7 (5.9\%) were employed at top level, 42 (35\%) were employed at middle level, and $71(59.1 \%)$ were employed at lower level.

Table 1

The Demographics of the Sample

\begin{tabular}{llcc}
\hline & Dimensions & Frequency & Percentage \\
\hline \multirow{3}{*}{ Gender } & Female & 41 & 34.2 \\
\multirow{3}{*}{ Nationality } & Male & 79 & 65.8 \\
& North Cyprus & 57 & 47.5 \\
& Turkey & 61 & 50.8 \\
& Other & 2 & 1.7 \\
\multirow{5}{*}{ Work Experience } & Less than One Year & 2 & 1.7 \\
& $1-5$ Years & 24 & 20 \\
& 6-10 Years & 48 & 40 \\
& 11-15 Years & 15 & 12.5 \\
Management Level & 16 Years or More & 31 & 25.8 \\
& Top Level Management & 7 & 5.9 \\
& Middle Level Management & 42 & 35 \\
& Lower Level Management & 71 & 59.1 \\
Education Level & Primary Education & 3 & 2.5 \\
& High School & 36 & 30 \\
& University & 71 & 59.1 \\
\hline Total & Master/PhD & 8 & 6.7 \\
\hline
\end{tabular}

Mean response for each leadership style was calculated from higher to lower. The mean scores of leadership styles were distributed as charismatic 3.81, democratic 3.76, laissez-faire 3.69, and autocratic 3.35. This implies that charismatic leadership style was perceived significantly more often compared to remaining leadership styles.

According to these findings, managers working at 4-star and 5-star hotels in Northern Cyprus mainly use the charismatic leadership style in which behaviour includes the leaders acting as a 
role model for followers, displaying a sense of power and confidence (Walter \& Bruch, 2009) and motivate the followers for the realization of common aspiration (Conger \& Kanungo, 1987; Shamir, House, \& Arthur, 1993). This finding is not consistent with Wood (1994) who indicates that hospitality managers are authoritarian, dictatorial, and heavy handed, and moreover, they hold a unitary view of managerial and leadership. However, the finding obtained is consistent with Neal, Finlay and Tansey (2005) who found that a very high level of charismatic authority exists among managers.

A probable explanation for this outcome may regard that positional characteristics of managers can shape their charismatic behaviour. In our study all respondents were employed as a manager. Shamir and Howell (1999) have considered charismatic behaviour to occur more frequently at higher hierarchical echelons. According to Walter and Bruch (2009), the position leaders occupy within the organisation may shape their charismatic behaviour.

Other explanation may be organisation's environment. Walter and Bruch (2009) have discussed the function of crisis situations as charismatic leadership antecedents. As with all industries, hospitality organisations have a number of crisis situations. Hotel and catering organisations are transitional communities particularly in respect of the relation between products, services, and customers. The transitional nature of customers places strains on product and service delivery, particularly as demand is erratic and uneven (Wood, 1994).

Burns (1978) claims that the conditions of uncertainty and ambiguity are distinctive of crisis situations and charismatic leadership traditionally has being associated with crisis. Shamir, House \& Arthur, (1993) agree that although crises situations may sponsor such leadership, but they are not necessary for its occurrence.

Moreover, in crises situations, people grow an elevated need for direction and certainty and will enthusiastically acknowledge a leader who displays self-confidence and provides a clear vision of the future. Thus, evidence suggests that individuals placed in demanding situations experience greater need for charismatic leadership (Mayo \& Poster, 2005).

One-Way ANOVA (Analysis of Variance) was used to test the relationship between the leadership styles and the demographic characteristics. As presented in Table 2, at a 0.05 significance level, nationality is statistically significantly related to laissez-faire leadership style at 0.009 . This indicates that nationality has an influence on laissez-faire leadership behaviour of the 4-star and 5-star hotel managers. On the other hand, significant relationship was not found between leadership styles and the other demographic characteristics (gender, management level, education level, and job experience). These findings are inconsistent with previous studies (e.g. Ali \& Ali, 2011; Eagly \& Johnson, 1990; Jamrok \& Neisan, 2013; Kozak \& Uca, 2008). Table 2 exhibits the one-way ANOVA differences of nationality and leadership styles.

Table 2

One-Way ANOVA Differences of Nationality and Leadership Styles

\begin{tabular}{cllclcr}
\hline Dimensions & & SS & DF & MS & F & Sig. \\
\hline \multirow{5}{*}{ Charismatic } & Between Groups & 0.57 & 2 & 0.28 & 0.78 & 0.45 \\
& Within Groups & 42.95 & 117 & 0.36 & & \\
& Total & 43.53 & 119 & & & 10.17 \\
& Between Groups & 1.14 & 2 & 0.57 & 1.75 & \\
& Wemocratic & 38.23 & 117 & 0.32 & & \\
& Total & 39.37 & 119 & & &
\end{tabular}




\begin{tabular}{|c|c|c|c|c|c|c|}
\hline Autocratic & $\begin{array}{l}\text { Between Groups } \\
\text { Within Groups } \\
\text { Total }\end{array}$ & $\begin{array}{c}1.57 \\
39.48 \\
41.06\end{array}$ & $\begin{array}{c}2 \\
117 \\
119\end{array}$ & $\begin{array}{l}0.78 \\
0.33\end{array}$ & 2.33 & 0.10 \\
\hline \multirow{3}{*}{ Laissez-faire } & Between Groups & 2.84 & 2 & 1.42 & 4.88 & $0.00^{*}$ \\
\hline & Within Groups & 34.13 & 117 & 0.29 & & \\
\hline & Total & 36.98 & 119 & & & \\
\hline
\end{tabular}

Leadership characteristic may vary across cultures (Den Hartog, House, Henges, \& RuizQuintanilla, 1999). According to House et al. (2004), culture is defined as a set of elements, namely shared purposes, values, attitudes, identities, and explanations or meanings of important events that result from usual and ordinary experiences of members of collectives and are transferred across age generations. According to Hofstede (1991) national culture refers to the values, attitude, and presumptions acquired in early childhood that differentiates one group of people from another. Leaders will not be successful unless they have the power and skill to accomplish the subordinates' expectations of what leadership behaviour ought to be within the certain cultural context (Kuchinke, 1999). Table 3 shows the mean analysis of nationality with leadership styles.

Table 3

Mean Analysis of Nationality with Leadership Styles

\begin{tabular}{|c|c|c|c|c|c|}
\hline Nationality & & Laissez-faire & Charismatic & Democratic & Autocratic \\
\hline \multirow{3}{*}{ North Cyprus } & Mean & 3.84 & 3.81 & 3.85 & 3.47 \\
\hline & $\mathrm{N}$ & 57 & 57 & 57 & 57 \\
\hline & SD & 0.51 & 0.59 & 0.54 & 0.55 \\
\hline \multirow{3}{*}{ Turkey } & Mean & 3.58 & 3.83 & 3.70 & 3.24 \\
\hline & $\mathrm{N}$ & 61 & 61 & 61 & 61 \\
\hline & $\mathrm{SD}$ & 0.56 & 0.60 & 0.59 & 0.61 \\
\hline \multirow{3}{*}{ Other } & Mean & 3.07 & 3.28 & 3.28 & 3.28 \\
\hline & $\mathrm{N}$ & 2 & 2 & 2 & 2 \\
\hline & $\mathrm{SD}$ & 0.50 & 1.01 & 0.80 & 0.20 \\
\hline \multirow{3}{*}{ Total } & Mean & 3.69 & 3.81 & 3.76 & 3.35 \\
\hline & $\mathrm{N}$ & 120 & 120 & 120 & 120 \\
\hline & SD & 0.55 & 0.60 & 0.57 & 0.58 \\
\hline
\end{tabular}

Turkish culture has long been explained as being high on collectivism and power distance (Hofstade, 1994). Finding of the GLOBE-Global Leadership and Organisational Behavioural Effectiveness, which constituted one of the more ambitious and influential cross-cultural leadership studies, revealed two major characteristics of Turkey to be in-group collectivism and power distance among 62 countries. According to the inter-country societal culture rankings of the GLOBE study Turkey is higher in terms of in-group collectivism (fourth), and power distance (tenth) (House et al., 2004). Hofstede (2001) claims that in high power distance culture only managers are involved in decision-making process, which is consistent with an autocratic leadership style not results of our study.

According to Hofstade (1994), Turkey is a collectivistic society where emphasize is on unity and group fidelity, leaders tend to work in groups, have a higher ordinal goal that they are working towards (E. Elsaid \& A. M. Elsaid, 2012), and superiors rely on fidelity of staff, reliability, and co-ordinated group relationship with others. Thus, this study indicates that the 
use of laissez-faire leadership is consistent with the basic assumptions underlying 'collectivism' in that managers obviously have trust and belief in their staff.

Moreover, one of the reasons of the result could be the influence of Islam. Yahchouchi (2009) assumes that Islam's influence on workplace actions may promote apprehension for in-group relationship above personal concerns, so both employees and employers have moral obligations to extend relationships that lead to increased team and organisational solidarity; thus, Islam community is supposed to be more collectivistic where cultural values promote conformity in group, section, or unit behaviour. In collectivistic cultures members are more likely to take up behaviours that warrant harmony. Consequently, it can easily be assumed that both Turkish Cypriots and Turkish national culture can promote laissez-faire leadership style.

Although Turkish Cypriot culture has effects of motherland Turkey such as having the same language and religion, Turkish Cypriots have cultural differences from Turkish people. Generally, it refers to the differences between their 'ways of life'. The culture of people living in Cyprus is not limited with the Turkish one. For years Cyprus has been affected by different cultures such as Ottoman, Greek, and British. Following this, a distinct culture constructed and this culture is different from the culture of Turkish people. Thus, historical background of the island and the cultural interaction of different civilisation resulting are mixture. Cypriot culture is mainly represented as a patchwork of Greek, English, and Turkish cultural elements. Accordingly, it is believed that some particular characteristics were gained with the past experience. In other words, especially past cohabitation with Greek Cypriots and fact that Cyprus was a colony of British Empire are pointed out as the reasons behind the unique position of the Turkish Cypriot culture. The significance of these two societies, are the fact that they signify the connection of Turkish Cypriots with the West and the Europe.

\section{Conclusion}

This study was conducted to investigate the dominant leadership style of the managers, as well as the influence of demographic factors on the leadership style of managers working at four and five star hotels in Northern Cyprus. The results of the study imply that the charismatic leadership style is dominated. However, it was observed that there is a statistically meaningful relationship between laissez-faire leadership style and nationality of managers exist. The results further imply that no statistically significant relationship was found between leadership style and gender, management level, education level, and job experience of managers. This means that the nationality of managers reinforces the laissez-faire leadership style.

Hotel organisations can view leadership development as a source of competitive advantage. Since the service industry tends to be labour intensive with diversified workforce and has increasingly changing environment, leadership skills may help organisations to utilize the available human resources more effectively and may help to increase performance.

Some limitations should be addressed. One limitation in this study was the time period of the research. It was the high season period of tourism in Northern Cyprus with high stress levels for managers. Most of the hotels were fully occupied and the managers were very busy, thus, if we have been conducted study at the low season period, it would have been possible to contact a larger group of managers. 
Another limitation considers the sample of the managers that was investigated in a range of four leadership styles. Drawing from a wider range would possibly have allowed for more generalization. In order to address these limitations, it is recommended to extend this research with a study of how culture and nationality influence leadership behaviour both in Northern Cyprus and in Turkey, using different styles and variables.

\section{References}

Al-Ababneh, M. (2013). Leadership style of managers in five-star hotels and its relationship with employee's job satisfaction. International Journal of Management \& Business Studies, 3(2), 93-98.

Ali, H., \& Ali, H. (2011). Demographics and spiritual leadership: Empirical evidence from Pakistan. Business \& Management Review, 1(10), 36-42.

Bass, B. M. (1990). Bass and Stogdill's handbook of leadership: Theory, research and managerial applications (3 ${ }^{\text {rd }}$ edition). New York: The Free Press.

Bass, B. M., \& Avolio, B. J. (1985). Transformational leadership, charisma, and beyond. Working paper, School of Management, State University of New York, Binghampton.

Burns, J. M. (1978). Leadership. New York: Harper \& Row.

Chen, Z. X., \& Francesco, A. M. (2000). Employee demography, organizational commitment, and turnover intentions in China: Do cultural differences matter? Human Relations, 53(6), 869-887.

Conger, J. A., \& Kanungo, R. N. (1987). Toward a behavioural theory of charismatic leadership in organisational settings. Academy of Management Review, 12(4), 637-647.

Den Hartog, D. N., House, R. J., Hanges, P. J., Antonio Ruiz-Quintanilla, S. A., Dorfman, P. W., Abdalla, I. A., ... Zhou, J. (1999). Culture specific and cross-culturally generalizable implicit leadership theories: Are attributes of charismatic/transformational leadership universally endorsed? Leadership Quarterly, 10(2), 219-252.

Eagly, A. H., \& Johnson, B. T. (1990). Gender and leadership style: A meta-analysis. Psychological Bulletin, 108, $233-256$.

Eagly, A. H., Johannesen-Schmidt, M. C., \& van Engen, M. L. (2003). Transformational, transactional, and laissez-faire leadership styles: A met analysis comparing women and men. Psychological Bulletin, 129(4), 569-591.

El Masry, S., Kattara, H., \& El Demerdash, J. (2004). A comparative study on leadership styles adopted by general managers: A case study of Egypt. Anatolia, 15(2), 109-124.

Elsaid, E., \& Elsaid, A. M. (2012). Culture and leadership: Comparing Egypt to the GLOBE study of 62 societies. Business \& Management Research, 1(2), 1-13.

Fincham, R. \& Rhodes, P. (2005). Principles of organisational behaviour (5 $5^{\text {th }}$ ed.). New York: Oxford University Press.

Gözel, D. (2011). Tourism demand in Northern Cyprus economy: Evidence from a demand model over the time period 1999Q12009Q4 (Master's thesis). Eastern Mediterranean University, Institute of Graduate Studies and Research, Deptartment of Business Administration, Famagusta: North Cyprus.

Hambrick, D., \& Mason, P. (1984). Upper echelons: The organisation as a reflection of its top managers. Academy of Management Review, 9(2), 193-206.

Hofstede, G. (1991). Culture and organisations: Software of mind. New York: McGraw-Hill.

Hofstede, G. S. (1994). The business of international business is culture. International Business Review, 3, 1-14.

Hofstede, G. (2001). Culture's consequences: Comparing values, behaviours, institutions, and organizations across nations. Thousand Oaks, CA: Sage.

House, R. J., Hanges, P. J., Javidan, M., Dorfman, P. W., \& Gupta, V. (2004). Culture, leadership and organisations: The GLOBE study of 62 societies. Thousand Oaks, CA: Sage Publications.

Ispas, A. (2012). The perceived leadership style and employee performance in Hotel industry- a dual approach. Review of International Comparative Management, 13(2), 294-304.

Jamrok, H., \& Neisari, M. (2013). The study of the leadership style of secondary school teachers in Kuchesfehan region. International Research Journal of Applied and Basic Sciences, 4(5), 1057-1061.

Kavanaugh, R. R., \& Ninemeier, J. D. (2001). Supervision in the Hospitality Industry (3 ${ }^{\text {rd }}$ ed.). Michigan: The Educational Institute of the American Hotel \& Lodging Association.

Kouzes, J. M., \& Posner, B. Z. (1995). The leadership challenge. San Francisco: CA Jossey-Bass Inc. 
Kozak, A. M., \& Uca, S. (2008). Effective factors in the constitution of leadership styles: A study of Turkish hotel managers. Anatolia: An International Journal of Tourism \& Hospitality Research, 19(1), 117-134.

Kuchinke, K. P. (1999). Leadership and culture: Work-related values and leadership styles among one company's U.S. and German telecommunication employees. Human Resource Development Quarterly, 10(2), 135-154.

Leavitt, H. J. (2003). Why hierarchies thrive. Harvard Business Review, 81(3), 96-102.

Mayo, M., \& Pastor, J. C. (2005). Workgroup gender diversity and charismatic leadership: Asymmetric effects among men and women. IE Working Paper, RH8-108-1.

Mitchel, S. (2000). American Generations-who they are. How they live. What they think ( ${ }^{\text {rd }}$ ed). Ithaca, N.Y.: New Strategic Publications, Inc.

Mullins, L. J. (1998). Managing people in the hospitality industry ( $3^{\text {rd }}$ ed.). Harlow: Addison Wesley Longman Limited.

Nadiri, H., \& Tanova, C. (2010). An investigation of role of justice in turnover intentions, job satisfaction and organisational citizenship behaviour in hospitality industry. International Journal of Hospitality Management, 29, 33-41.

Neal, M., Finlay, J., \& Tansey, R. (2005). My father knows the minister: A comparative study of Arab women's toward leadership authority. Women in Management Review, 20(7), 478-497.

Nebel, E. E., \& Stears, G. K. (1977). Leadership in hospitality industry. The Cornell Hotel \& Restaurant Admiinistration Quarterly, 18(3), 69-76.

Newstrom, J. W. (2007). Organisational behaviour: Human behaviour at work (12 ${ }^{\text {th }}$ ed.). New York, NY: McGraw-Hill.

Northouse, P. G. (2007). Leadership: Theory and practice ( $4^{\text {th }}$ ed.). Thousand Oaks, CA: Sage.

Offermann, L. R., \& Hellmann, P. S. (1997). Culture's consequences for leadership behavior: National values in action. Journal of Cross-Cultural Psychology, 28(3), 342-351.

Okumuş, F., \& Hemmington, N. (1998). Management of change process in hotel companies: An investigation at operational level. International Journal of Hospitality Management, 17, 363-374.

Raguz, I. V. (2007). The interdependence between characteristics and leadership style of Managers in the hospitality industry in Dubrovnik-Neratva country: Empirical research. Management, 12(2), 57-68.

Robbinson, D. (2005). Organisational behaviour and analysis: An integrated approach. Harlow, Essex: Pearson Education Limited.

Rosener, J. B. (1990). Ways women lead. Harvard Business Review, 68(6), 119-125.

Sawati, M. J., Anwar, S., \& Majoka, M. I. (2013). Do qualification, experience and age matter for principals leadership styles? International Journal of Academic Research in Business \& Social Sciences, 3(7), 403-413.

Shamir, B., House, R. J., \& Arthur M. B. (1993). The motivational effects of charismatic leadership: A self-concept based theory. Organisation Science, 4, 577-594.

Shamir, B. \& Howell, J. M. (1999). Organisational and contextual influences on the emergence and effectiveness of charismatic leadership. Leadership Quarterly, 10, 257-283.

Testa, M. R. (2007). A deeper look at national culture and leadership in the hospitality industry. Hospitality Management, 26(2), 468-484.

Tsui, A. S., \& O’Reilly, C. A. (1989). Beyond simple demographic effects: the importance of relational demography in superiorsubordinate dyads. Academy of Management Journal, 32(2), 402-423.

Walter, F., \& Bruch, H. (2009). An affective events model of charismatic leadership behaviour: A review, theoretical integration, and research agenda. Journal of Management, 35(6), 1428-1452.

Wood, R. C. (1994). Organisational behaviour for hospitality management. Oxford: Butterworth-Heinemann Ltd.

Yahchouchi, G. (2009). Employees' perceptions of Lebanese managers' leadership styles and organisational commitment. International Journal of Leadership Studies, 4(2), 127-140.

Yukl, G. A. (2002). Leadership in organisations. Upper Saddle River, NJ: Prentice-Hall 